\title{
German Venture Capitalists' Investment Criteria Over Financing Stages
}

Florian Eisele (E-mail: florian.eisele@uni-tuebingen.de), University of Tuebingen, Germany Christine Haecker (E-mail: christine.haecker@ uni-tuebingen.de), University of Tuebingen, Germany

Ralf Oesterle (E-mail: ralf.oesterle @ uni-tuebingen.de), University of Tuebingen, Germany

\begin{abstract}
This study empirically explores the respective importance of a variety of criteria relevant for the investment decision of German venture capitalists. We find that the relative importance of criteria varies with investment stages. In all stages, however, criteria in the personality of management category as well as the appreciation potential of the acquired equity stake are considered crucial. Irrelevant are various market characteristics, dividend potential, as well as the desired independence level of management. Thus, this analysis provides all participants in the venture capital $(V C)$ process with a comprehensive understanding of the parameters underlying the VC investment decision in Germany.
\end{abstract}

\section{Introduction}

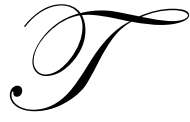

he criteria that are the basis for an investment decision in the German VC market are thus far unclear. Additionally, prior studies do not distinguish between the relative importance of criteria in the three investment stages. Since the VCs' decision to invest is based on those investment criteria, it is highly desirable to be cognizant of the relative importance of respective decision parameters. This study aims to fill this void in research by exploring the importance of a variety of criteria relevant for the investment decision of German venture capitalists.

Our study focuses explicitly on the German VC market. Hereby, we categorize VC projects into three investment stages based on the respective degree of maturity. These VC projects differ in regard to required management skills and in the degree of inherent uncertainty about expected earnings.

\section{German Venture Capital Market And Financing Stages}

The German venture capital market ${ }^{1}$ has considerably gained in importance within the last twenty years (Table 1). After Great Britain, Germany is now the second largest VC market in Europe (Bundesverband deutscher Kapitalgesellschaften ${ }^{2}$ (or BVK), 2001). In 2001, there were 5,974 members with new investments of 4.4 billion euros ( $\$ 5.1$ billion) and a total market volume of 15.8 billion euros ( $\$ 18.3$ billion).

Accordingly, numerous theoretical and empirical studies have explored various areas within the venture capital (VC) investment field. So far, however, there is a research gap in respect to the investment criteria of German venture capitalists (VCs). Since the VCs' decision to invest is

\footnotetext{
The study is restricted to the formal VC market, where the VC firm exhibits an intermediary function between investors and borrowers. The informal market for venture capital between business angels and borrowers is not explored in this study due to its low volume and the difficulties in gathering data. For the relatively minor significance of business angels in the German VC market see Oesterle/Sohns (2002).

2 The BVK, or German Venture Capital Association, comprises German venture capital firms, private equity companies, and representatives of foreign venture capitalists operating in Germany. Its members account for more than $90 \%$ of total market volume.
}

\begin{tabular}{|c|c|}
\hline Year & Average growth (in \%) \\
\hline 2001 & 48.1 \\
$1997-2000$ & 36.1 \\
$1991-1996$ & 11.2 \\
$1983-1990$ & 22.0 \\
\hline
\end{tabular}


based on those investment criteria, it is highly desirable to be cognizant of the relative importance of respective decision parameters. This study aims to fill this void in research by exploring the importance of diverse investment criteria.

The empirical analysis is based on the German VC market and differentiates between three stages of VC investment, allowing for different degrees of inherent uncertainty and required management skills (see Figure 1). Another investigation goal, hence, is to assess the relative importance of investment criteria in disparate maturity stages. Early and expansion stage financing have generally comprised the majority of German VC investments. ${ }^{3}$ In 2000, early stage investments and expansion stage investments accounted for $35.9 \%$ and $35.1 \%$ of all VC investments, respectively (BVK, 2000b). Additional late stage financing devices, such as management buy-outs or leveraged buy-outs, are not considered since they are not relevant for this study.

Figure 1: Venture Capital Investment Stages (Schmeisser, 2000).

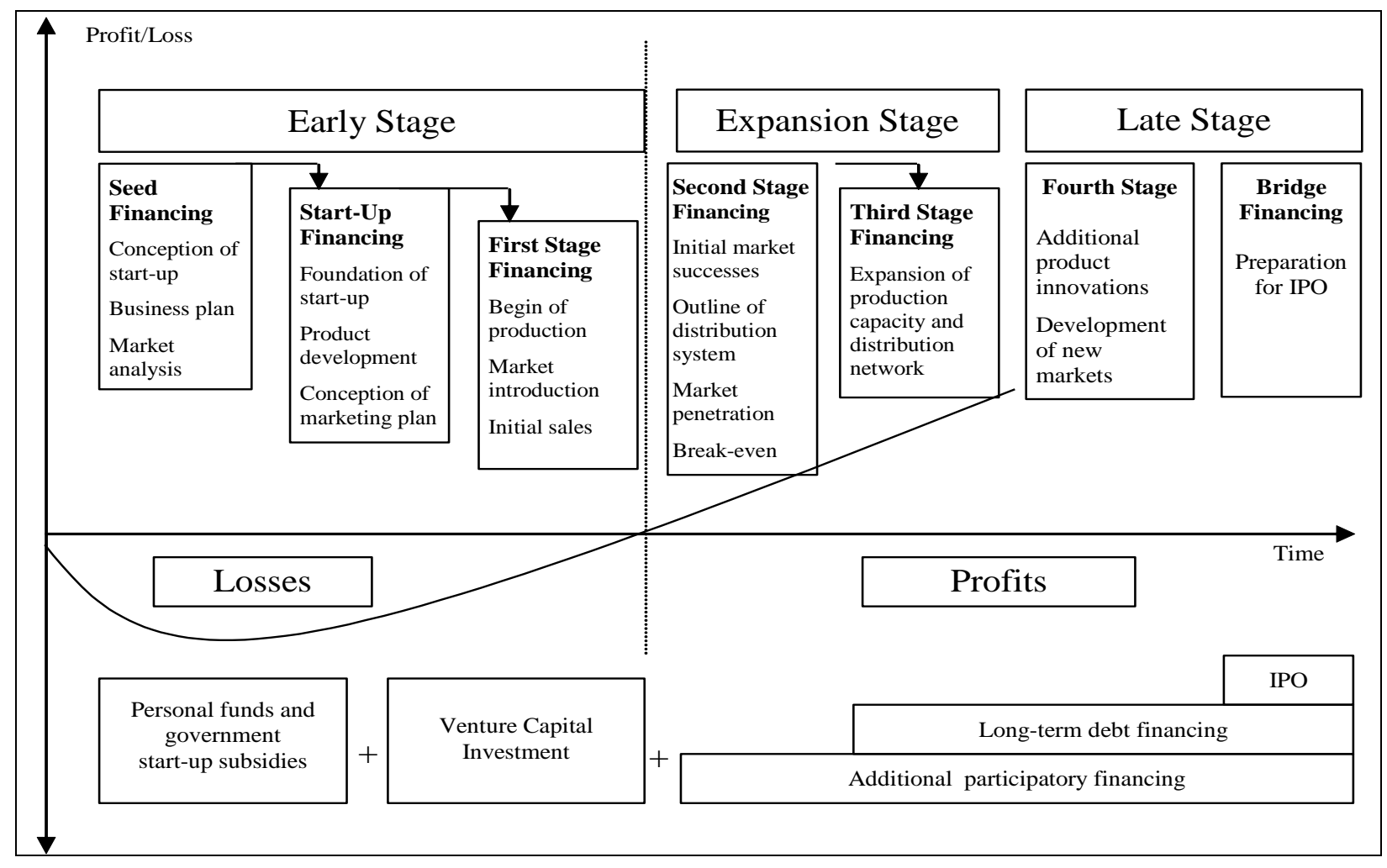

As initial investment stage, seed financing is provided to the entrepreneur to prove a business concept. ${ }^{4}$ This includes market research, development of initial product, and building a management team. Start-up capital is provided to companies completing product development and initial marketing. First-stage financing is supplied to companies that have exhausted initial production and marketing budgets and require additional resources to initiate full-scale manufacturing and sales.

3 Note that in the year 2001 and 2002 the respective MBO/MBI/LBO investment percentage of $37 \%$ and $45 \%$ deviated from its historical average of 20\% (BVK, 2002). Consequently, the percentage of both early and expansion stage investment decreased in 2001 and 2002.

4 As the eventual success of the venture is uncertain in this financing stage (Ruhnka/Young, 1987), VC financing is very risky and thus rare in the seed stage. Debt financing also does not seem suitable for young firms, because of the discrepancy between the fixed nature of interest payments and a loss-making venture. German seed financing is thus predominantly based on the entrepreneur's personal means and government start-up subsidies (Schefczyk, 2000). 
Note that our definitions for second-stage, third-stage, and fourth-stage financing deviate from the common US definitions. Also, our fourth stage definition differs from bridge financing. Our definitions are adapted to reflect the differing circumstances in the German VC industry. A widespread German phenomenon is that large companies might still be privately held while having an international presence. See Schmeisser (2000) for a detailed study on the German VC investment cycle.

Second stage financing is provided to companies for the expansion of their domestic production and distribution system. Third-stage financing is granted to companies with growing sales and positive cash flows for major international expansions. Fourth stage financing for additional product innovations or the development of new markets is appropriate for relatively mature companies focusing on maintaining their market share (Zemke, 1995; Engelmann, 2000). Thus, our fourth stage financing category denotes a separate development stage of the corporation, which is equal to the degeneration stage in the life cycle of the original product. Bridge financing primarily serves as a "financial bridge" until additional financing can be secured through an IPO. ${ }^{5}$

\section{Literature Review}

Rational investment decisions are made based on the valuation of the expected future cash flows from the investment project. VCs will only invest in a project, if their expected rate of return is high enough to compensate for the risk they are incurring. The quality of VCs' portfolios depends on the success of the VCs' risk analysis, which, in turn, depends on the criteria on which the $\mathrm{VC}$ investment decision is based. The identification and assessment of such investment criteria has been an important research field since the ' $80 \mathrm{~s}$.

Zopounidis (1994) provides an overview of the various studies exploring the investment decision of VCs. Wells (1974) attempted to ex post determine specific investment criteria of VCs that differentiated successful ventures from unsuccessful ventures. Later studies explored the relative weight of such criteria (Benoit, 1975; Poindexter, 1976; Dixon, 1991). Tyebjee and Bruno (1984) and MacMillan et al. (1985) used descriptive methods as well as factor and cluster analyses for the determination of different investor classes with different risk attributes. Subsequently, many studies were based on MacMillan et al.'s 1985 study (e.g. Kaplan/Stroemberg, 2001; Pandey, 1995; Knight, 1994; Ray/Turpin, 1993; Ray 1991).

In Germany, only the studies by Laub (1989), Schröder (1992), and Brettel (2002) have explored the VC investment criteria perspective. These studies were beneficial as they identified important investment criteria. Yet, neither study explored the differing importance of respective investment criteria over all financing stages. Additionally, only the study of Brettel distinguished between profit-oriented and state owned VCs. Our study endeavors to close the gap in research that still exists despite prior studies. Differences in the studies generally arise from the respective importance of the criteria as well as from the inclusion of "soft criteria".

The number of criteria explored varies greatly among studies. For instance, Guild/Bachher (1996) explored 96 criteria, whereas Shepherd (1999) considered only 6 criteria. Additionally, the considered criteria themselves vary, as well as their resulting importance. Table 2 gives the criteria that we explore in our study and shows whether these criteria were included in important VC studies over the years. Thereby, the triangles indicate the tested criteria, while the solid triangles represent the dominant criteria of each study. Management quality is the most important criterion that VCs base their investment decision on ${ }^{6}$, closely followed by the thorough familiarity of management with the target market. As Table 2 shows, a high growth rate of the target market is also very important. Compared with the high importance of management quality, product criteria, market criteria, as well as financial criteria are less decisive.

\footnotetext{
5 The "Neuer Markt" for young and innovative growth companies, which is comparable to the NASDAQ, was founded in March 1997, and is to be reorganized and renamed to Prime Standard by the end of 2003. This market is highly important for the German VC market, as it provides an additional and important exit possibility for VCs (Schmeisser, 2000). For a study on optimal exit strategies for VCs see Neus/Walz (2001).

6 There are also studies that question the dominance of the management quality criterion. Zacharakis/Meyer (1998) show that VCs report basing their investment decision on management criteria; in reality, however, the investment decision rather seems to be based on market criteria. Hall/Hofer (1993) also show management criteria to be of lesser importance in the initial venture screening process.
} 
Table 2: Assessment Of Our Investment Criteria In Respect To The Criteria Examined In Various VC Studies. ${ }^{7}$

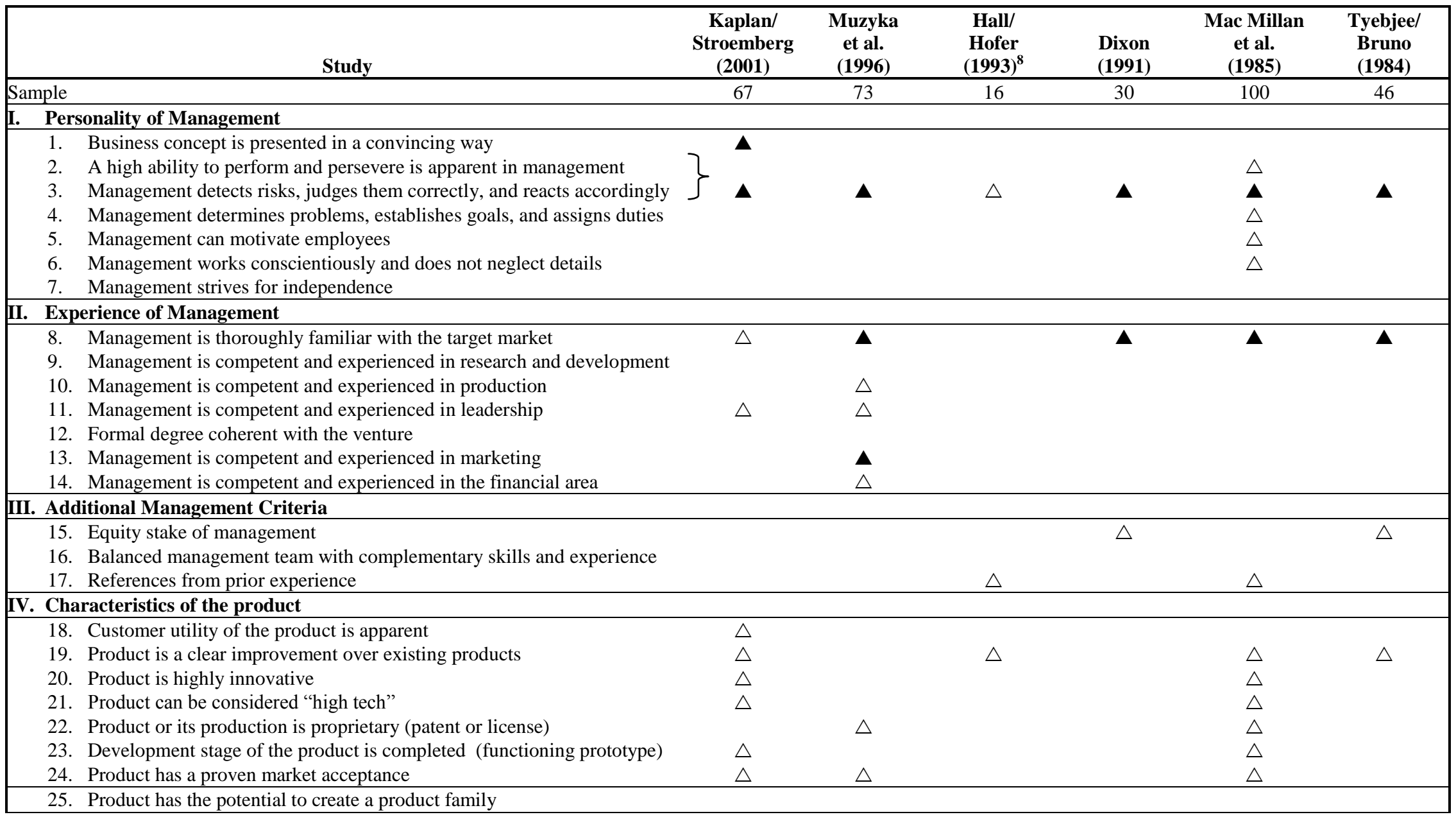

7 Note that most studies defined only a broad investment criterion of management quality. As our study distinguishes in various management character traits, we summarized criterion 2-4 in this table to represent the broad criterion of management quality.

Also note that the triangles indicate the tested criteria, while the solid triangles depict the dominant criteria.

8 Due to the structure of this analysis, no dominant criteria could be deduced. 


\begin{tabular}{|c|c|c|c|c|c|c|}
\hline Study & $\begin{array}{c}\text { Kaplan/ } \\
\text { Stroemberg } \\
(2001)\end{array}$ & $\begin{array}{c}\text { Muzyka } \\
\text { et al. } \\
\text { (1996) }\end{array}$ & $\begin{array}{c}\text { Hall/ } \\
\text { Hofer } \\
(1993)^{8}\end{array}$ & $\begin{array}{l}\text { Dixon } \\
(1991) \\
\end{array}$ & $\begin{array}{c}\text { Mac Millan } \\
\text { et al. } \\
(1985)\end{array}$ & $\begin{array}{c}\text { Tyebjee/ } \\
\text { Bruno } \\
(1984)\end{array}$ \\
\hline \multicolumn{7}{|l|}{ V. Characteristics of the relevant market } \\
\hline 26. Target market possesses a high growth rate & $\mathbf{\Delta}$ & $\triangle$ & $\triangle$ & $\triangle$ & $\triangle$ & $\Delta$ \\
\hline 27. Little competition in the target market during the first three years & $\triangle$ & $\triangle$ & $\triangle$ & & $\triangle$ & \\
\hline 28. Existing distribution channels & & $\triangle$ & & & & \\
\hline 29. International markets can be opened with the venture & & & & & $\triangle$ & \\
\hline 30. Entirely new markets can be opened with the venture & & & & & $\triangle$ & \\
\hline \multicolumn{7}{|l|}{ VI. Financial Investment Criteria } \\
\hline 31. High appreciation potential of acquired equity stake & & & & & $\triangle$ & \\
\hline 32. Ability to cash out & $\triangle$ & $\triangle$ & $\triangle$ & & $\triangle$ & $\triangle$ \\
\hline 33. Scale and chance of later funding rounds & $\triangle$ & $\triangle$ & & & $\triangle$ & \\
\hline 34. Dividend potential from acquired stake & & & & & & \\
\hline 35. Required annual ROI (in \%) & $\triangle$ & $\triangle$ & & & $\boldsymbol{\Delta}$ & \\
\hline 36. Expected annual rate of return from the investment portfolio (in \%) & & & & & & \\
\hline
\end{tabular}


So-called soft criteria aim at assessing the quality of the founder and the management team. There are studies that concentrate mainly on hard criteria (Muzyka et al., 1996; Tyebjee/Bruno, 1984; Dixon, 1991), probably because such criteria are easier quantifiable. However, soft-criteria might be important indicators of successful venture ideas, and thus may be critical decision parameters. Dubini (1989) finds the highest correlation between venture success and the criteria "attention to details" and "ability to detect risks and react accordingly". Thus, we include both soft and hard decision parameters in our study.

\section{Empirical Study}

\subsection{Scope Of The Study}

In contrast to prior German studies, we will focus on profit-oriented VC firms and distinguish between the three financing stages for the assessment of criteria importance. Because profit-oriented investors and not-for-profit firms have different investment goals, one may expect a differing degree of importance of respective investment criteria. Thus, only VC firms that base their investment decisions on risk-return considerations are considered. Additionally, only those VC firms that directly invest in the equity of the firm are included. The direct participation in the success of a start-up with price appreciations additionally highlights the profit-orientation of those VC firms.

Only VC firms with private investors, banks, insurances, and pension fund investors are considered, as those VC firms can be assumed to be profit-oriented. VC firms with government and corporate investors are not included, since such investors might primarily be interested in providing financial aid, lending support, or enhancing strategic goals. Geographically, the study is limited to VC firms that invest primarily in Germany.

\subsection{The Sample}

Based on the BVK (2000a) VC membership directory, 91 participants were selected according to the above criteria. Of these $91 \mathrm{VC}$ firms, 61 firms were willing to participate, and 30 questionnaires were eventually returned in Winter 2001. With a total of 91 suitable VC firms for our study, the 30 respondents imply a participation rate of $33 \%$.

Over the three financing stages, Table 3 compares the relative investment frequency of the sample with the relative investment frequency of the population. As it is common practice to invest in projects that are in differing financing cycles, many VC firms are listed simultaneously in several development stages.

The sample is assumed to be representative of the population, since the distribution of observations of the sample roughly equals the population distribution. A $\chi^{2}$-test proves this point, as the absolute value of the test statistic of 0.187 at a significance level of $\alpha=0.05$ is significantly lower than the critical value of 5.99 with $\mathrm{m}-1=2$ degrees of freedom.

Table 3: Relative Frequency Of Observations Over Financing Stages (BVK, 2000a).

\begin{tabular}{|lcccc|}
\hline \multicolumn{1}{|c}{ Financing Stages } & Early Stage & Expansion Stage & Late Stage & Sum \\
\hline Relative frequency of observation in population & 0.387 & 0.344 & 0.269 & 1 \\
Relative frequency of observation in sample & 0.388 & 0.362 & 0.25 & 1 \\
\hline
\end{tabular}

\subsection{Criteria Selection And Assessment Of Importance}

Relevant investment criteria for the empirical study are selected based on prior U.S. VC studies and are modified for additional practical parameters relevant for the German market. ${ }^{9}$ We classify our criteria into the broad

\footnotetext{
9 The utilized questionnaire was developed with the assistance of German VC firms. For instance in the product category, investment criteria could thus be identified that had received little attention in prior U.S. studies.
} 
categories (i) management, (ii) product, (iii) market, and (iv) financial investment. The assessment of investment criteria importance is incorporated by an ordinal scale consisting of values 0 to 3 (see Table 4).

Table 4: Specification Of Parameter Values And Inherent Substance. ${ }^{10}$

\begin{tabular}{|ccccl|}
\hline Value & & Assessment & & \multicolumn{1}{c|}{ Substance of assessment } \\
\hline 0 & $=$ & not relevant & $\Rightarrow$ & No influence on the investment decision. \\
1 & $=$ & desirable & $\Rightarrow$ & Improves the prospect of a positive investment decision. \\
2 & $=$ & important & $\Rightarrow$ & Significant factor for the investment decision, unless other factors compensate \\
& for the non-fulfillment of this criterion. \\
3 & $=$ & absolutely necessary & $\Rightarrow$ & Absolutely necessary for a positive investment decision. \\
\hline
\end{tabular}

The surveyed VC firms were asked to assign these values to all criteria over the financing stages, thereby indicating the respective importance of investment criteria. Thus, criteria that are absolutely necessary for a positive investment decision can be selected and separated from those that are negligible.

\section{Interpretation Of Results}

\subsection{Preliminary Remarks}

The numerous considered investment criteria are grouped under the following six categories: Personality of management

- $\quad$ Experience of management

- $\quad$ Additional management criteria

- $\quad$ Characteristics of the product

- $\quad$ Characteristics of the relevant market

- $\quad$ Financial investment criteria.

Based on Table 4, every survey participant assigns a parameter value from 0 to 3 to each investment criterion. Then, the mean and standard deviation for each investment criterion is computed (see Table 5). The total mean over all investment criteria is relatively homogeneous over financing stages, always remaining roughly between 2.0 and 2.1. Yet, the importance of numerous criteria varies considerably over financing stages. Figure 2 graphically shows these variations for each criterion by depicting the individual means of all considered criteria as indicators of investment criteria importance.

Table 6 shows the percentage of total responses indicating parameter value 3 for each investment criterion over financing stages. A value of 3 indicates absolute necessity, i.e. the respective investment criterion is crucial for a positive investment decision. The proportion test compares the value assignments over financing stages and tests those variations for significance. Very high percentage values show that there is unity among VC investors about the importance of a specific criterion, implying that a negative investment decision will follow if the essential criterion remains unrealized. Those absolutely necessary criteria are important for VC firms as well as for start-ups that need to raise funds. Only rarely are criteria that are important in the early stage overtaken by other criteria in later stages. This implies that there are central investment criteria that are highly important regardless of the financing stage. Yet, the results also show that the importance of different criteria varies over financing stages. Even if those changes are not always significant, one can nevertheless detect tendencies that seem reasonable.

\footnotetext{
${ }^{10}$ See also MacMillan et al. (1985) for a similar analysis.
} 


\section{Compatibility With Existing Literature}

\subsection{Management Criteria}

Table 5 and 6 clearly show that management abilities are highly important investment criteria. The early stage investment decision of practically all VCs (96\% combined with a small standard deviation) depends on the ability of management to present the business concept in a convincing way. Generally, management personality is regarded as indispensable; merely the ability of management to work conscientiously as well as management independence (criteria $6 \& 7$ ) are considered relatively inconsequential.

The resulting assumption that management abilities inversely influence the risk of an investment decision can be greatly reinforced by the study of Tyebjee/Bruno (1984). Based on a correlation analysis, Tyebjee/Bruno showed that the correlation coefficient between the independent variable "managerial capabilities" and the dependent variable "risk" had the largest negative correlation. VCs intuitively consider this correlation by emphasizing management personality strongly in their investment decision. As Table 2 shows, all the listed studies found management quality to be a dominant investment criterion. Additionally, Kaplan/Stroemberg (2001) identified the high importance of management presenting the business concept in a convincing way.

Thorough experience of management is on average observed to be less important. Solely the "familiarity of management with the target market" is considered important in all three stages (high mean and low standard deviation). Tyebjee/Bruno (1984), Mac Millan et al. (1985), Dixon (1991), as well as Muzyka et al. (1996) also regard the familiarity of management with the target market as a dominant decision parameter. As could be intuitively expected, the R\&D abilities of management are considered more important in the first stage than in later stages, as R\&D and the establishment of a feasible product are central in the first stage and concluded in later stages. In contrast to Muzyka et al. (1996) ${ }^{11}$, we do not find the marketing abilities of management criteria to be a dominant decision parameter. In expansion and late stage, only $50 \%$ and $47 \%$ of respondents regard marketing abilities as crucial, in early stage even less than $15 \%$.

Additional management criteria $(15-17)$ are of only average significance, with an average evaluation of "important" (equal to parameter value 2 of Table 4). This is quite remarkable, as all three criteria appear to be substantial loss minimizing criteria. A larger equity stake of management, for instance, can - especially in the early stage - be regarded as an indication of confidence in the own business idea, as well as it reduces potential agency costs. Apparently however, VC investors do not consider the link between equity stake and management commitment as necessary (Dixon, 1991; Tyebjee/Bruno, 1984). This is especially true in later stages, as there is typically less uncertainty and loss potential. A balanced management team with complementary skills and experience (16) becomes increasingly more important in expansion and late stage, possibly due to the heterogeneity and complexity of the tasks that have to be mastered in these stages (Robinson, 1987).

Noteworthy is the fluctuation of importance assessments over development stages. 'Soft' criteria assessing the personality of management $(1-7,16)$ are considered more important in the early stage than 'harder' management experience criteria $(8-15,17)$. Management experience in production, leadership, marketing, and in the financial area becomes more important over the stages; whereas the importance of R\&D experience (9) diminishes progressively. The percentage of VCs considering management experience in leadership and in the financial area as absolutely necessary (parameter value 3) has increased significantly from $29 \%$ and $23 \%$ in early stage to $79 \%$ and $60 \%$ in late stage, respectively. From the soft criteria pool, especially motivation factors (5) and perseverance (2) decrease from $65 \%$ and $89 \%$ in early stage to $32 \%$ and $55 \%$ in late stage, respectively. These results are consistent with prevailing opinion (Bascha/Walz, 2001). Because the expansion stage involves the expansion of production and distribution channels, pertinent experience gains in importance.

\footnotetext{
${ }^{11}$ Note that Muzyka et al. (1996) is the only study in Table 2 that even considered the marketing abilities of management as an investment criterion.
} 


\subsection{Characteristics Of The Product}

As can be seen in Table 2, Kaplan/Stroemberg (2001) and Mac Millan et al. (1985) consider similar product criteria. However they do not classify any criterion of this category as absolutely crucial. We find that the dominant criterion of the product characteristics category is the apparent customer utility of the product (18). Customer utility, product superiority, and innovative character (18-20) are regarded as most important, as they are mandatory for a competitive advantage in the target market. Roure/Keeley (1990) similarly find that the superiority and uniqueness of the product is essential for the $\mathrm{VC}$ financing decision. The importance of the product being high-tech is surprisingly low ${ }^{12}$; only $50 \%$ and $23 \%$ of respondents regard this criterion as absolutely necessary in early stage and late stage, respectively. This reasoning is only partly accurate, however, since the high standard deviation indicates that assessments vary greatly among VCs.

Both proprietary characteristics (22) and proven market acceptance of the product (24) become increasingly important with the full-scale distribution of the product in the later stages. The percentage of respondents considering proprietary characteristics and proven market acceptance as absolutely necessary increases from $30 \%$ or $16 \%$ in early stage to $50 \%$ or $62 \%$ in late stage, respectively.

The development stage of the product ${ }^{13}$ does not seem to be a crucial criterion. These findings are unexpected, as less uncertainty surrounding the technical feasibility of the product should facilitate a better evaluation of the risk potential of the investment.

The potential of the product to create a product family was not evaluated as investment criterion in either of the studies listed in Table 2. Although this criterion is regarded as important in German literature (Engelmann, 2000), we find it to be of only minor empirical impact on the German VC investment decision.

\subsection{Characteristics Of The Relevant Market}

We find that all criteria of this category are less relevant. The percentage of respondents considering the fulfillment of respective criteria as absolutely necessary is always below $50 \%$.

The dominant criterion of the characteristics of the relevant market category $(\mathrm{V})$ is a high growth rate of the target market (26); although the percentage of respondents considering the fulfillment of this criterion as absolutely necessary is only between $48 \%$ and $37 \%$ over the stages. In contrast, Tyebjee/Bruno (1984) regard the growth rate of the market and its size as absolutely critical. Similarly, Kaplan/Stroemberg (2001) found that $69 \%$ of VCs considered the size of the target market and its growth rate in their investment decision.

Little competition (27) and existing distribution channels (28) are merely regarded as desirable or important. Even in the late stage, where functioning distribution channels are essential for a thorough market penetration, only $30 \%$ of respondents assess existing distribution channels as absolutely necessary. One possible inference is that VCs intend to handle the establishment of suitable distribution channels as part of their customary advising function (Zemke, 1995).

The high requirements of U.S. VCs, regarding access to international markets or new markets as critical (Bygrave/Timmons, 1992), do not seem to play an important role in Germany. The new market potential (30) was never regarded as absolutely necessary; and only 3 respondents considered international market potential as mandatory.

\footnotetext{
$1240 \%$ of new VC investments in Germany are in the technology industry or related businesses (BVK, 2001).

13 As VCs expect functioning prototypes in expansion and late stage, the importance of this criterion was not examined in later stages.
} 
Table 5: Average Parameter Values Indicating Importance Of Each Investment Criterion

In All Three Financing Stages (Based On Table 3) ${ }^{14}$ And Respective Standard Deviations

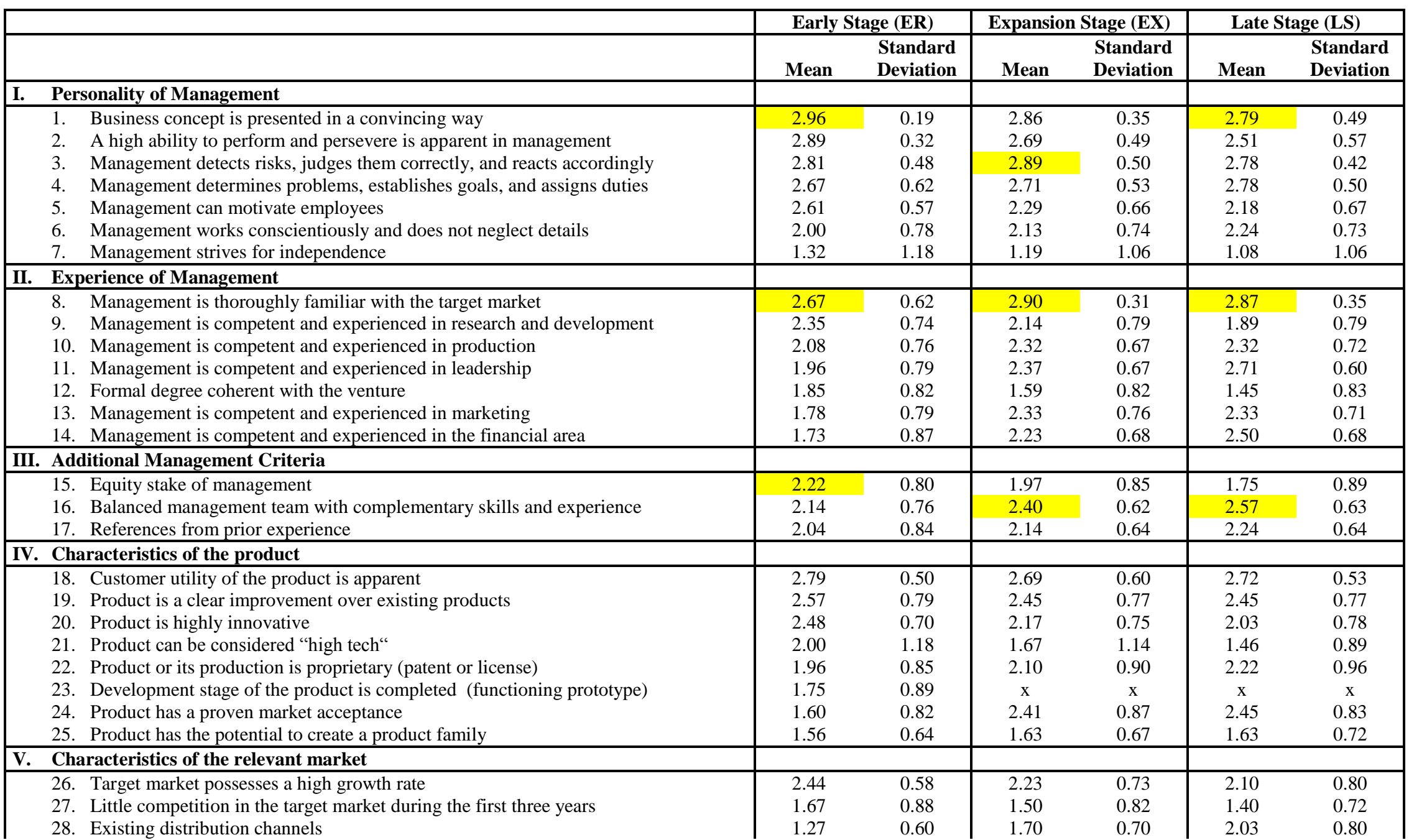

14 The most important criterion per category for each financing stage is highlighted. ' $\mathrm{x}$ ' implies that the criterion was not considered for respective stage. 


\begin{tabular}{|c|c|c|c|c|c|c|}
\hline & \multicolumn{2}{|c|}{ Early Stage (ER) } & \multicolumn{2}{|c|}{ Expansion Stage (EX) } & \multicolumn{2}{|c|}{ Late Stage (LS) } \\
\hline & Mean & $\begin{array}{c}\text { Standard } \\
\text { Deviation }\end{array}$ & Mean & $\begin{array}{l}\text { Standard } \\
\text { Deviation }\end{array}$ & Mean & $\begin{array}{l}\text { Standard } \\
\text { Deviation }\end{array}$ \\
\hline 29. International markets can be opened with the venture & 1.19 & 0.89 & 1.33 & 0.76 & 1.53 & 0.79 \\
\hline 30. Entirely new markets can be opened with the venture & 0.77 & 0.65 & 0.67 & 0.62 & 0.59 & 0.50 \\
\hline \multicolumn{7}{|l|}{ VI. Financial Investment Criteria } \\
\hline 31. High appreciation potential of acquired equity stake & 2.97 & 0.17 & 2.87 & 0.34 & 2.77 & 0.43 \\
\hline 32. Ability to cash out & 2.29 & 0.72 & 2.34 & 0.67 & 2.50 & 0.68 \\
\hline 33. Scale and chance of later funding rounds & 1.48 & 1.17 & 1.04 & 1.12 & $\mathrm{x}$ & $\mathrm{x}$ \\
\hline 34. Dividend potential from acquired stake & 0.22 & 0.42 & 0.40 & 0.62 & 0.64 & 0.91 \\
\hline 35. Required annual ROI (in \%) & $46 \%$ & $22 \%$ & $34 \%$ & $17 \%$ & $26 \%$ & $11 \%$ \\
\hline 36. Expected annual ROI of portfolio (in \%) & $31 \%$ & $9 \%$ & $24 \%$ & $7 \%$ & $22 \%$ & $8 \%$ \\
\hline 37. Maximum investment duration (in years) & 5.90 & 2.28 & 5.00 & 2.15 & 4.00 & 2.46 \\
\hline
\end{tabular}

Figure 2: Mean Parameter Values Indicating The Importance Of Each Investment Criterion In Individual Financing Stages.

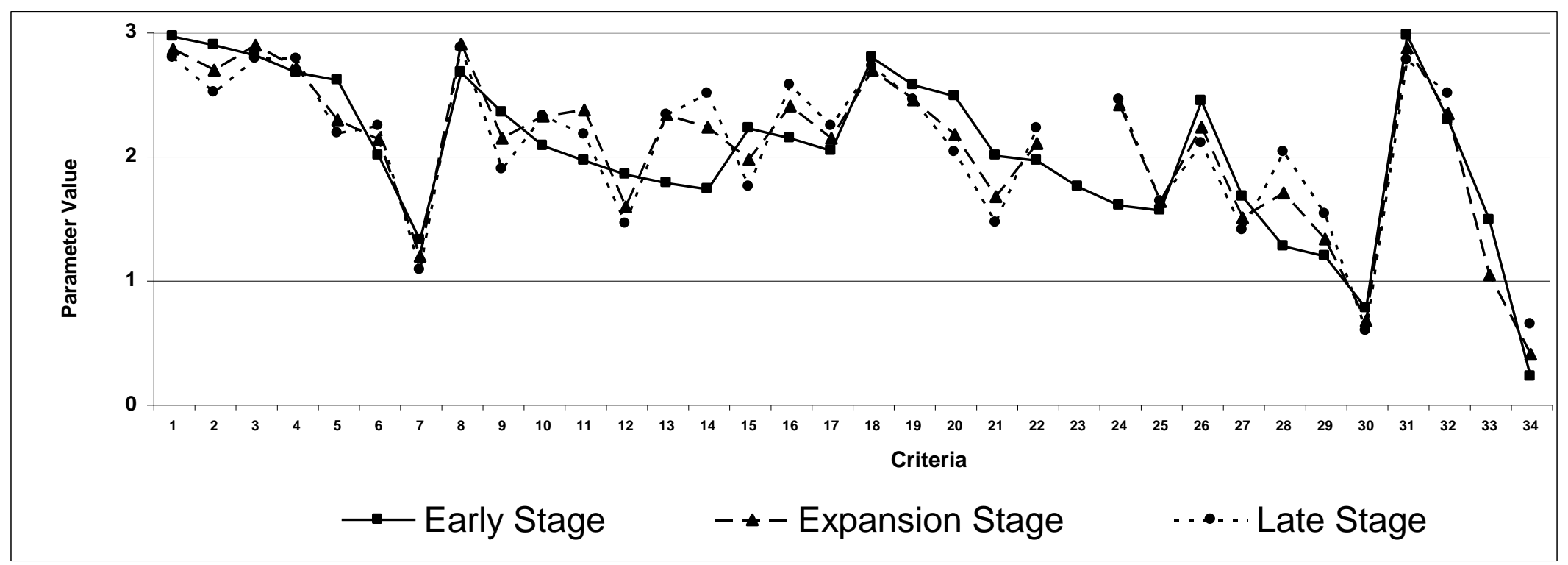


Table 6: Percentage Of Total Responses Indicating Parameter Value 3 For Each Investment Criterion Over Financing Stages. ${ }^{15}$

\begin{tabular}{|c|c|c|c|c|c|c|c|}
\hline & & \multicolumn{3}{|c|}{$\%$ Of Value 3 = Absolutely Necessary } & \multicolumn{3}{|c|}{$\begin{array}{l}\text { Proportion Test: z-Values Of } \\
\text { Financing Stage Comparisons }\end{array}$} \\
\hline & & Early Stage & $\begin{array}{l}\text { Expan. } \\
\text { Stage }\end{array}$ & Late Stage & $\begin{array}{l}\text { Early - } \\
\text { Expan. }\end{array}$ & $\begin{array}{l}\text { Expan. - } \\
\text { Late }\end{array}$ & Early - Late \\
\hline \multicolumn{8}{|c|}{ I. Personality of Management } \\
\hline & 1. Business concept is presented in a convincing way & 0.963 & 0.862 & 0.828 & 1.323 & 0.363 & 1.637 \\
\hline & 2. A high ability to perform and persevere is apparent in management & 0.889 & 0.621 & 0.552 & $2.316^{* *}$ & 0.533 & $2.791^{* *}$ \\
\hline & 3. Management detects risks, judges them correctly, and reacts accordingly & 0.852 & 0.867 & 0.759 & -0.161 & 1.065 & 0.877 \\
\hline & 4. Management determines problems, establishes goals, and assigns duties & 0.741 & 0.750 & 0.821 & -0.079 & -0.651 & -0.724 \\
\hline & 5. Management can motivate employees & 0.654 & 0.393 & 0.321 & $1.918^{*}$ & 0.558 & $2.443^{* *}$ \\
\hline & 6. Management works conscientiously and does not neglect details & 0.259 & 0.310 & 0.379 & -0.423 & -0.533 & -0.961 \\
\hline & 7. Management strives for independence & 0.240 & 0.115 & 0.111 & 1.167 & 0.049 & 1.227 \\
\hline \multicolumn{8}{|c|}{ II. Experience of Management } \\
\hline & 8. Management is thoroughly familiar with the target market & 0.741 & 0.900 & 0.863 & -1.578 & 0.402 & -1.203 \\
\hline & 9. Management is competent and experienced in research and development & 0.500 & 0.345 & 0.214 & 1.165 & 1.097 & $2.197^{* *}$ \\
\hline & 10. Management is competent and experienced in production & 0.320 & 0.429 & 0.464 & -0.814 & -0.269 & -1.072 \\
\hline & 11. Management is competent and experienced in leadership & 0.286 & 0.467 & 0.786 & -1.419 & $-2.502^{* *}$ & $-3.751^{* *}$ \\
\hline & 12. Formal degree coherent with the venture & 0.222 & 0.138 & 0.103 & 0.823 & 0.403 & 1.209 \\
\hline & 13. Management is competent and experienced in marketing & 0.148 & 0.500 & 0.467 & $-2.814^{* *}$ & 0.258 & $-2.583^{* *}$ \\
\hline & 14. Management is competent and experienced in the financial area & 0.231 & 0.367 & 0.600 & -1.103 & $-1.808^{*}$ & $-2.785^{* *}$ \\
\hline \multicolumn{8}{|c|}{ III. Additional Management Criteria } \\
\hline & 15. Equity stake of management & 0.407 & 0.300 & 0.214 & 0.848 & 0.745 & 1.549 \\
\hline & 16. Balanced management team with complementary skills and experience & 0.357 & 0.467 & 0.633 & -0.846 & -1.297 & $-2.102^{* *}$ \\
\hline & 17. References from prior experience & 0.360 & 0.276 & 0.345 & 0.664 & -0.568 & 0.116 \\
\hline \multicolumn{8}{|c|}{ IV. Characteristics of the product } \\
\hline & 18. Customer utility of the product is apparent & 0.821 & 0.759 & 0.759 & 0.582 & 0.000 & 0.582 \\
\hline & 19. Product is a clear improvement over existing products & 0.750 & 0.700 & 0.600 & 0.426 & 0.812 & 1.216 \\
\hline & 20. Product is highly innovative & 0.593 & 0.367 & 0.310 & $1.706^{*}$ & 0.457 & $2.123^{* *}$ \\
\hline & 21. Product can be considered "high tech" & 0.500 & 0.296 & 0.231 & 1.487 & 0.541 & $1.982^{* *}$ \\
\hline & 22. Product or its production is proprietary (patent or license) & 0.296 & 0.379 & 0.500 & -0.656 & -0.918 & -1.542 \\
\hline & 23. Development stage of the product is completed (functioning prototype) & 0.250 & $\mathrm{x}$ & $\mathrm{x}$ & - & - & - \\
\hline & 24. Product has a proven market acceptance & 0.160 & 0.621 & 0.621 & $-3.436^{* *}$ & 0.000 & $-3.436^{* *}$ \\
\hline & 25. Product has the potential to create a product family & 0.037 & 0.067 & 0.100 & -0.500 & -0.467 & -0.929 \\
\hline & Characteristics of the relevant market & & & & & & \\
\hline
\end{tabular}

15 Proportion test: * implies a level of significance of at least $10 \%$; * implies a level of significance of at least $5 \%$; ' $\mathrm{x}$ ' implies that the criterion was not considered for the respective stage. Note that all respondents not always ranked all investment criteria. Therefore, sporadically smaller $\mathrm{n}$ can result for certain investment criteria. 


\begin{tabular}{|c|c|c|c|c|c|c|}
\hline & \multicolumn{3}{|c|}{$\%$ Of Value 3 = Absolutely Necessary } & \multicolumn{3}{|c|}{$\begin{array}{l}\text { Proportion Test: z-Values Of } \\
\text { Financing Stage Comparisons }\end{array}$} \\
\hline & Early Stage & $\begin{array}{l}\text { Expan. } \\
\text { Stage }\end{array}$ & Late Stage & $\begin{array}{l}\text { Early - } \\
\text { Expan. }\end{array}$ & $\begin{array}{l}\text { Expan. - } \\
\text { Late } \\
\end{array}$ & Early - Late \\
\hline 26. Target market possesses a high growth rate & 0.481 & 0.400 & 0.367 & 0.619 & 0.266 & 0.877 \\
\hline 27. Little competition in the target market during the first three years & 0.222 & 0.133 & 0.067 & 0.881 & 0.861 & $1.688^{*}$ \\
\hline 28. Existing distribution channels & 0.038 & 0.100 & 0.300 & -0.892 & $-1.936^{*}$ & $-2.549^{* *}$ \\
\hline 29. International markets can be opened with the venture & 0.074 & 0.033 & 0.100 & 0.688 & -1.035 & -0.345 \\
\hline 30. Entirely new markets can be opened with the venture & 0.000 & 0.000 & 0.000 & - & - & - \\
\hline \multicolumn{7}{|l|}{ VI. Financial Investment Criteria } \\
\hline 31. High appreciation potential of acquired equity stake & 0.963 & 0.867 & 0.767 & 1.283 & 1.001 & $2.130^{* *}$ \\
\hline 32. Ability to cash out & 0.444 & 0.467 & 0.600 & -0.168 & -1.035 & -1.174 \\
\hline 33. Scale and chance of later funding rounds & 0.238 & 0.125 & $\mathrm{x}$ & 0.990 & - & - \\
\hline 34. Dividend potential from acquired stake & 0.000 & 0.000 & 0.067 & - & -1.415 & -1.366 \\
\hline
\end{tabular}




\subsection{Financial Investment Criteria}

The dominant criterion in the financial investment category is the appreciation potential of the equity stake (31). Out of all 6 categories, respondents regard this criterion as the most vital factor for an investment decision in the early stage, with a low standard deviation indicating conformity of opinions.

Liquidity of the investment is also an important investment criterion. Only of minor importance is the participation in additional financing cycles (33) and dividend potential (34). Note that the criterion dividend potential was not considered in any of the studies that are shown in Table 2.

Interesting are the decreasing values of required ROI (35), expected portfolio ROI (36), and maximum investment duration (37) over investment stages. One might conclude from the difference between required and expected ROI that the VCs expect some of their investment decisions not to pay off. One of the surveyed VCs stated that of a total of 20 investments he expects 10 start-ups to go bankrupt in early stage, 5 start-ups to just breakeven, 3 start-ups to fulfill the ROI expectations, and only 2 start-ups to be a "super deal". The decreasing disparity between required and expected annual ROI over the investment stages also shows that the percentage of bankruptcies is expected to be smaller in later financing stages. Ruhnka/Young (1987) also find larger loss probabilities for early stages. Noteworthy is also the high standard deviation of the required ROI. Differing investment duration and differing intensity of VCs' support to the new venture might explain these findings.

\section{Conclusion}

Prior studies find that management quality is the most important criterion that VCs base their investment decision on, closely followed by the thorough familiarity of management with the target market. A high growth rate of the target market is also very important. Compared with the high importance of management quality, criteria such as product criteria, market criteria, and financial criteria are less decisive.

Our findings deviate somewhat from the dominant criteria of prior studies (Table 2). We also find that 'management quality' is a very important investment criterion. Similar to Kaplan/Stroemberg (2001), we find that the ability of management to present the business concept in a convincing way is mandatory. 'Familiarity of management with the target market' is considered crucial by Tyebjee/Bruno (1984), Mac Millan et al. (1985), Dixon (1991), as well as Muzyka et al. (1996). Although we find this criterion to be quite important in early stage, it is only considered absolutely necessary in expansion stage and late stage. Our additional crucial criteria 'apparent customer utility of product' and 'high appreciation potential of equity stake' were only evaluated by Kaplan/Stroemberg (2001) and Mac Millan et al. (1985), respectively. Finally, we find the criterion of 'being a clear improvement over existing products' to be vital in early stage, whereas prior literature does not regard this criterion as absolutely critical. In line with prior studies, we find 'product characteristics' and 'market characteristics' to be successively less important. Irrelevant in our study are various 'market characteristics', 'dividend potential', as well as the 'desired independence level of management'.

The results show that the importance of individual criteria varies with financing stages. On average, the importance of respective investment criteria is similar in expansion and late stage. Deviations in importance of criteria occur between the early stage and the later stages. This indicates that a start-up company faces different conditions, a fact that is thus incorporated in the German VC investment decision.

Consequently, one may categorize into criteria that are irrelevant to the investment decision, criteria that are relevant, and criteria that are crucially important for a positive investment decision (see Table 7). For companies endeavoring VC funding, this distinction will make the investment decision of VCs more transparent. Modifications may be possible, e.g. in the composition of the management team, that will increase the likelihood of a positive investment decision. Additionally, investors in VC funds will be able to deduce how their invested capital is used. VCs themselves can compare their important investment criteria to the findings of this article. This approach might be especially valuable for criteria with a high standard deviation. Thus, this analysis provides all participants in the $\mathrm{VC}$ process with a comprehensive understanding of the parameters underlying the $\mathrm{VC}$ investment decision in Germany. 
Table 7: Most Important And Least Important Investment Criteria In Individual Financing Stages (Based On Table 5).

\begin{tabular}{|c|c|c|c|c|c|c|c|c|c|}
\hline \multicolumn{4}{|c|}{ Early Stage } & \multicolumn{3}{|c|}{ Expansion Stage } & \multicolumn{3}{|l|}{ Late Stage } \\
\hline Rank & Criterion & Mean & $\begin{array}{l}\text { Standard } \\
\text { deviation }\end{array}$ & Criterion & Mean & $\begin{array}{l}\text { Standard } \\
\text { deviation }\end{array}$ & Criterion & Mean & $\begin{array}{l}\text { Standard } \\
\text { deviation }\end{array}$ \\
\hline 1 & $\begin{array}{l}\text { (31) High appreciation potential } \\
\text { of acquired equity stake }\end{array}$ & 2.97 & 0.17 & $\begin{array}{l}\text { (8) Management is thoroughly } \\
\text { familiar with target market }\end{array}$ & 2.90 & 0.31 & $\begin{array}{l}\text { (8) Management is thoroughly } \\
\text { familiar with target market }\end{array}$ & 2.87 & 0.35 \\
\hline 2 & $\begin{array}{l}\text { (1) Business concept presented } \\
\text { convincingly }\end{array}$ & 2.96 & 0.19 & $\begin{array}{l}\text { (3) Management detects risks, } \\
\text { judges them correctly, and acts } \\
\text { accordingly }\end{array}$ & 2.89 & 0.50 & $\begin{array}{l}\text { (1) Business concept presented } \\
\text { convincingly }\end{array}$ & 2.79 & 0.49 \\
\hline 3 & $\begin{array}{l}\text { (2) Management has high } \\
\text { ability to perform and persevere }\end{array}$ & 2.89 & 0.32 & $\begin{array}{l}\text { (31) High appreciation potential } \\
\text { of acquired equity stake }\end{array}$ & 2.87 & 0.34 & $\begin{array}{l}\text { (4) Management determines } \\
\text { problems, establishes goals, and } \\
\text { assigns duties } 16\end{array}$ & 2.78 & 0.50 \\
\hline 4 & $\begin{array}{l}\text { (3) Management detects risks, } \\
\text { judges them correctly, and acts } \\
\text { accordingly }\end{array}$ & 2.81 & 0.48 & $\begin{array}{l}\text { (1) Business concept presented } \\
\text { convincingly }\end{array}$ & 2.86 & 0.35 & $\begin{array}{l}\text { (3) Management detects risks, } \\
\text { judges them correctly, and acts } \\
\text { accordingly }\end{array}$ & 2.78 & 0.42 \\
\hline 5 & $\begin{array}{l}\text { (18) Customer utility of the } \\
\text { product is apparent }\end{array}$ & 2.79 & 0.50 & $\begin{array}{l}\text { (4) Management determines } \\
\text { problems, establishes goals, and } \\
\text { assigns duties }\end{array}$ & 2.71 & 0.53 & $\begin{array}{l}\text { (31) High appreciation potential } \\
\text { of acquired equity stake }\end{array}$ & 2.77 & 0.43 \\
\hline 30 & $\begin{array}{l}\text { (7) Management strives for } \\
\text { independence }\end{array}$ & 1.32 & 1.18 & $\begin{array}{l}\text { (29) Access to international } \\
\text { markets }\end{array}$ & 1.33 & 0.76 & $\begin{array}{l}\text { (12) University degree } \text { or } \\
\text { training coherent with the } \\
\text { venture }\end{array}$ & 1.45 & 0.83 \\
\hline 31 & $\begin{array}{l}\text { (28) Existing distribution } \\
\text { channels }\end{array}$ & 1.27 & 0.60 & $\begin{array}{l}\text { (7) Management strives for } \\
\text { independence }\end{array}$ & 1.19 & 1.06 & $\begin{array}{l}\text { (27) Little competition in focus } \\
\text { market during first three years }\end{array}$ & 1.40 & 0.72 \\
\hline 32 & $\begin{array}{l}(29) \text { Access to international } \\
\text { markets }\end{array}$ & 1.19 & 0.89 & $\begin{array}{l}\text { (33) Desired participation in } \\
\text { additional financing cycles }\end{array}$ & 1.04 & 1.12 & $\begin{array}{ll}\text { (7) Management strives for } \\
\text { independence }\end{array}$ & 1.08 & 1.06 \\
\hline 33 & $\begin{array}{l}\text { (30) Access to entirely new } \\
\text { markets }\end{array}$ & 0.77 & 0.65 & $\begin{array}{l}\text { (30) Access to entirely new } \\
\text { markets }\end{array}$ & 0.67 & 0.62 & $\begin{array}{l}\text { (34) Dividend potential from } \\
\text { acquired stake }\end{array}$ & 0.64 & 0.91 \\
\hline 34 & $\begin{array}{l}\text { (34) Dividend potential from } \\
\text { acquired stake }\end{array}$ & 0.22 & 0.42 & $\begin{array}{l}\text { (34) Dividend potential from } \\
\text { acquired stake }\end{array}$ & 0.40 & 0.62 & $\begin{array}{l}\text { (30) Access to entirely new } \\
\text { markets }\end{array}$ & 0.59 & 0.50 \\
\hline
\end{tabular}

16 Criterion 3 and 4 have the same mean in late stage. Criterion 4 is ranked third, however, because it has a higher percentage of total responses indicating parameter value 3 . 


\section{References}

1. Bascha, A./Walz, U. 2001. "Financing practices in the German venture capital industry - An empirical assessment", Working paper.

2. Benoit, J. L. 1975. Venture capital investment behavior: The risk-capital investor in new company formation and expansion in France. Unpublished doctoral dissertation, University of Texas, Austin.

3. Brettel, M. 2002. "Entscheidungskriterien von Venture Capitalists: Eine empirische Analyse im internationalen Vergleich", Die Betriebswirtschaft 62: 305-325.

4. Bundesverband Deutscher Kapitalbeteiligungsgesellschaften (BVK), 2002. Statistik 2001. Berlin.

5. Bundesverband Deutscher Kapitalbeteiligungsgesellschaften, 2001. Statistik 2001. Berlin.

6. Bundesverband Deutscher Kapitalbeteiligungsgesellschaften, 2000a. Jahrbuch 2000. Berlin.

7. Bundesverband Deutscher Kapitalbeteiligungsgesellschaften, 2000b, Statistik 2000. Berlin.

8. Bygrave, W. D./Timmons, J. A. 1992. Venture capital at the crossroads. Boston 1992.

9. Dixon, R. 1991. "Venture capitalists and the appraisal of investments". Omega 19(5): 333-344.

10. Dubini, P. 1989. "Which venture capital entrepreneurs have the best chances of succeeding?" Journal of Business Venturing 4(1): 123-132.

11. Engelmann, A. 2000. Moderne Unternehmensfinanzierung: Risikokapital für Unternehmensgründung und wachstum. Frankfurt am Main 2000.

12. Guild, P. D./Bachher, J. S. 1996. "Equity investment decisions for technology based ventures", IJTM, Special issue on resources for SME innovation 12(7\&8): 787-795.

13. Hall, J./Hofer, C. 1993. "Venture capitalists' decision criteria in new venture evaluation". Journal of Business Venturing 8(1): 25-42.

14. Kaplan, S./Stroemberg, P. 2001. "Characteristics, contracts, and actions: Evidence from venture capitalist analyses", Working paper.

15. Knight, R. M. 1994. "Criteria used by venture capitalists: A cross cultural analysis", International Small Business Journal 13(1): 26-37.

16. Laub, U. 1989. Zur Bewertung innovativer Unternehmensgründungen im institutionellen Zusammenhang: Eine empirisch gestützte Analyse. München 1989.

17. MacMillan, I. C./Siegel, R./Narasimha, S. P. N. 1985. "Criteria used by venture capitalists to evaluate new venture proposals", Journal of Business Venturing 1: 119-128.

18. Muzyka, D. F./Birley, S./Leleux, B. 1996. "Trade-offs in the investment decisions of European venture capitalists", Journal of Business Venturing 11(1): 273-287.

19. Neus, W./Walz, U. 2001. "Exit timing of venture capitalists in the course of an initial public offering", GEABA-Discussion Paper DP 01-14 (http://www.geaba.de). June 2001.

20. $\quad$ Oesterle, R./Sohns, B. 2002. "Business Angels”, Das Wirtschaftsstudium 5: 661.

21. Pandey, I. M. 1995. "Venture capital investment criteria used by venture capitalists in India", Presented at $7^{\text {th }}$ Annual International Symposium on Small Business Finance, April $24^{\text {th }}$.

22. Poindexter, J. B. 1976. "The efficiency of financial markets: The venture capital case", Unpublished doctoral dissertation, University of Georgia, Athens.

23. Ray, D. M. 1991. "Venture capital and entrepreneurial development in Singapore", International Small Business Journal 10(1): 11-26.

24. Ray, D. M./Turpin, D. V. 1993. "Venture capital in Japan”. International Small Business Journal 11(4): 39-56.

25. Robinson, R. B. 1987. "Emerging strategies in the venture capital industry", Journal of Business Venturing 2: 53-77.

26. Roure, J. B./Keeley, R. H. 1990. "Predictors of success in new technology based ventures". Journal of Business Venturing 5: 201-220.

27. Ruhnka, J. C./Young, J. E. 1987. “A venture capital model of the development process for new ventures”, Journal of Business Venturing 2: 167-184.

28. Schefczyk, M. 2000. Erfolgsstrategien deutscher Venture Capital-Gesellschaften. 2. Aufl., Stuttgart 2000.

29. Schmeisser, W. 2000. "Venture Capital und Neuer Markt als strategische Erfolgsfaktoren der Innovationsförderung", Finanz-Betrieb 2: 189-193. 
30. Schröder, C. 1992. Strategien und Management von Beteiligungsgesellschaften: Ein Einblick in Organisationsstrukturen und Entscheidungsprozesse von institutionellen Eigenkapitalinvestoren. Baden-Baden 1992.

31. Shepherd, D. A. 1999. "Venture capitalists' assessment of new venture survival", Management Science 45(5): 621-632.

32. Tyebjee, T. T. / Bruno, A. V. 1984. "A model of venture capitalist investment activity", Management Science 30(9): 1051-1066.

33. Wells, W. A. 1974. Venture capital decision making. Unpublished doctoral dissertation, Carnegie Mellon University.

34. Zacharakis, A. L. / Meyer, G. D. 1998. "A lack of insight: Do venture capitalists really understand their own decision processes?", Journal of Business Venturing 13(1): 57-76.

35. Zopounidis, C. 1994. "Venture capital modeling: Evaluation criteria for the appraisal of investments", The Financier ACMT 1(2): 54-64.

36. Zemke, I. 1995. Die Unternehmensverfassung von Beteiligungskapital-Gesellschaften: Analyse des institutionellen Designs Deutscher Venture Capital-Gesellschaften. Wiesbaden 1995.

Notes 
Notes 